\title{
XXXIII. Particulars of the successful treatment of a case of hydrophobia; with observations, \&c.
}

\section{Rice Winne}

To cite this article: Rice Winne (1813) XXXIII. Particulars of the successful treatment of a case of hydrophobia; with observations, \&c. , Philosophical Magazine Series 1, 42:185, 194-202, DOI: 10.1080/14786441308638314

To link to this article: http://dx.doi.org/10.1080/14786441308638314

册 Published online: 27 Jul 2009.

Submit your article to this journal $\sqsubset \pi$

Џ Article views: 2

Q View related articles $\sqsubset$ 


\section{[ 194 ]}

XXXIII. Particulars of the succesiful Treatment of a Case of Hydrophobia; with Observations, \&c. By Rıсв WinNe, Apothecary, Shrewsbury.

$\mathrm{O}_{\mathrm{N}}$ the morning of January the 22d, 1513, a strange pointer bitch was observed by a young woman on the road leading from Monkmoor to Shrewsbury. She thonght there was something uncommon in her look; and having a mastiff $\log$ along with her, which was in the habit of attacking every dog she set him at, she immediately endeavoured to put them to fight, purposely that the road might be free for her escape. The mastiff, instead of advancing, instantly slunk behind, and seemed much frightened. The pointer then flew at the female, and tore her cloak; she did not receive any further injury. The bitch proceeded, and was met by a man driving cows, by one of which she was attacked, and in the encounter the cow was bitten in the leg; but upon its being washed and examined, the owner could not perceive that the skin was broken. The pointer next entered a house, and bit a kitten, which was destroyed; - from thence she went to Emstrey (about two miles distant), and, without the least provocation, bit a greshound, which was likewise killed; she then proceeded to Chilton, about a mile further. A little beyoud, on the road, she attacked a chiid who was carrying a bas. ket of meat; the meat was thrown down, but was not noticed by the bitch. She repeatedly flew at the child, and tore her bonnet and cloche's, but did not inflict any wound. The child, alarmed, ran forward to Atcham, which is but a short distance, and seeing the dog coming that way, she cried out for help. A man un'vading coal was going to her assistance, when the bitch, without barking, or giving any other warning, rushed under the waggon and attacked him; she flew two or three times at bis face, and, when he was endenvouring t' protert him.elf, she bit him in the left hand. She then crossed the road, and attacked and bit a dog, which was destroyed. She was pursued about half a mile, and was shot by a kexper belonging to the Right Honourable Lord Beruick.

Abraham Cook, tat. 38, the person who was bitten by the pointer bitch, is of widdle stature, of fiorid complexion, at times suffers from dysepsia, and after great exertion, or excess in drinking, has been subject to fainting fits. In about an hour after he was bitten in the hand, he was persuaded by his friends to walk to Shrewsbury; and the bitten part was excised by Mr. Thomas Sutton, surgeon. 
The wound soon healed, and he continued in good health and spirits, always making light of the accident, until Friday the 5th of February, on the morning of which day he first began to complair: of an uneasiness and soreness in that part of the hand where he had received the injury. On Saturdav, and Sunday, it became gradually worse; and on Monday morning, after an almost sleepless night, he arose with increased pain and soreness in his hand, attended with head-ache, sickness, and great oppression at the pit of his stomach; his breathing was difficult; and his bowels were costive, Notwithstanding, he went to his work, but very soon became much worsc. He was prevaled upon to drink some warm beer, and was immediately seized with violent and excessive vomitings of green bile. He with difficulty returned to his home, and on his way was much distressed, as he believed the people who were passing by were deter. mined to ride over him; and he felt chilled, and very uncomfortable, at the appearance of the river, which he passed over. His wife seeing him so ill (without having any suspicion of the nature of the disease) pressed him to drink some water; he showed a great dread of it, and could not be prevailed upon to drink any, assigning, as the reason of his objection, the pain and vomiting he experienced after swallowing the beer. She then procured some surfeit water, to which he made the same objection; she pressed it to his mouth, but his looks so terrified her she cannot recollect whether any was swallowed; if there was, it must have been a very small quantity. All the symptoms rapidly increased : his eyes were inflamed, and staring; his face was likewise inflaned, and his features were contorted, and indicated the greatest distress and anxiety: it was with difficulty he was detained in his bed, and he appeared to be watching, and anxious to escape some object that occasioned his distress. At this time (abour one o'clock P.M,) I was passing through the village, and was desired to visit him. I found him in the situation related. In a very short time afterwards, his left hand, arm, and his head were convulsed. I pressed him to drink some water, but could not prevail; and althougb I did not sbserve any additional horror at the moment $I$ offered it, sill it was evident he was so much convulsed as not to be able to drink.

Being convinced in my own mind of the nature of the disease, 1 was anxious for the advice and assistance of $\mathrm{my}$ much-esteemed friend, $\mathrm{Mr}$. Thomas Sutton; yet I was also 2ware that no time should be lost, and that the delay of an 


\section{Successful Trealment of a Case of Hydropholia.}

hour might hazard the life of our patient. The pulse was from 70 to 80 beats in a minute, varying in strength and regularity.

I had recourse to the abstraction of twenty ounces of blood, taken from a large orifice, and the time of taking it did not exceed six minutes. He fainted, and remained for an hour with scarcely a perceptible pulse; and it was evident the whole time, his diserse was abating. His countenance became more composed, and much paler; his eyes were less inflamed; the convulsions ceased; and when recovering from his faintmess, his first request was that he might be allowed to drink some water; and when it was brought to him he seemed much to enjoy it. I now left him ; desiring, if any return of his disease took place, 1 might be immediately acquainted with it. I sent him pills, containing, to each dose, one grain of opium, three grains of the submuriate of mercury, and one grain of James's powder, which were directed to be taken every three hours.

The pulse, on Monday afternoon, after the bleeding, and after the faintness had subsided, was reduced to 55 beats in the minute, and was regular. [The same alteration tcok place after the second bleeding, and did not exceed 60 during the remainder of his illness.]

On Tuesday morning, at seven o'clock, I again visited him; when I was intormed that between four and five o'clock the preceding afternoon his bowels had been freely opened, and previous to his taking any medicine. They had not again been moved, nor had he any feeling as though they were likely. He had drunk coffce, and balm tea, in the night; but he had an aversion to them; it still hurt him to swallow. He had made a sufficient quantity of water, which was high-coloured, but without sediment. He had slept a litile, at intervals, but was much distressed by dreams of hearses, and various accidents, but all of which he said bad not troubled him half so much as when he yesterday thought he was pursued in his room by a dog. He seemed agitated, and said he was dreadlully ill, and should never slcep again. There were corsulgive startings in his hand, wrist, and shoulders. He told me he thought there was sumething alive in his wrist. He refused to take either coffee or water. Ilis countenance was composed and thoughtful; he said his neighbours bad been making a noise on purpose all night, and every thing went throughts his brains. He started at the slightest sound, or motion; and his sense of hearing was morbidly acute. The pulse was full, but unequal, beating about 80 strokes in the mi- 
nute; his countenance was rather flushed. I considercd it necessary to repeat the biceding ${ }^{*}$, and when about ten ounces were taken, he fainted; his pulse was again scarcely to be filt. He continued in this state for about half an hour, and he was perfectly composed and free from convulsion.

I visited him again that afternoon, about five o'clock. His wife, about three o'clock, for a moment observed a twitching in his shoulders; he had regularly taken the submuriate of mercury, opium, and James's powder, but his bowels had not been again relieved. The part of his hand of which he had complained was still sore upon pressure; and he was directed every eight hours to rub in one drachm of the strong mercurial ointment, and to continue the pills. He still complained of pain about the middle of the chest, particularly when he swallowed liquids; and in consequence had not taken much food; what he had swallowed was chiefly broth, pudding, and coffee.

On Wednesday I saw him comfortable, excepting that his bowels continued costive; lie had a strong opening mixture sent him, and after taking of it twice, the purpose was effected. lle regularly, until this time, continued the pills, with the submuriate of mercury, \&c. when it was thought advisable, as he had passed healthy bile, not to repeat them oftener than ouce in six hours.

On Thursclay morning, when I visited him, he was comfortable, and bul pased a cood night; his mouth was becoming sore, and heated. In the evening I was sent for to him; he had been siting up for some sime, and had been much fatigued, and fainted. When I arrived, his wife said she was sorry I had becn troubled to come again that day, as the fit was nothing like what I had scen before, and was not more than such as he had been accustomed to when he had been drinking hard, or was much tired; and that it was against her consent that the messenger came. He had recovered by the time I reached his house, and I was satisfied from appearances she was right; and I left him without any apprehension.

Since that time he has not experienced one untoward symptom. The medicines were continued for nine days, the mouth remained sore for nearly three weeks.

I here wish to mention, that inimediately on my return from Atcham on Monday, the 8th, the first afternoon I visited the patient, I called upon Mr. Thomas Sutton, and requested him in take the earliest opportunity of observing

- The blood in neither instance appeared buffy. N 3 


\section{Successful Treatment of a Case of Hydropholia.}

the case, and begged that he would have the kindness to suggest any thing that he thought likely to be of service. $\mathrm{He}$ and Mr. Sutton, as well as others of the profession, have been present.

\section{Olservations.}

In our observations, we are naturally led, first, to investigate the disease as it appeared in the dog: secondly, the injury which followed the wound she inflicted in the hand of Abraham Cook : and, lastly, the result of the treat ment that was in consequence adopted.

She is described, as not being known by any one; her eyes were heavy, and had a glassy appearance. There was a flow of frothy saliva from tier mouth; her belly was remarkably gaunt, and the dogs she worried, although larger; and superior in strength, were at orice frightened and dismayed. Her mode of attack was sudden, and without wartiing, for in no ore instance was she heard to bark: all of which symptoms are related by authors as appertaining to canine madness.

The illness of Abraham Cook commenced on the 5th of Fobruary, fourteen days after the accident. He then first perceived an uneasy sensation in the part thai was bitten: On the 6 th, it gradually became more painful. On the 7 th, he had violent head-ache, tomitings, and pain at the pit of his stomach : his bowels were confined. When he drank some beer; it aggravated his sufferings. He suspected people were determined purposely to ride over him; and his wretchedness was greatly increased by the chilliness he experienced as he passed over the river; atid afterwards, when he reached his home, he refused to take any liquid, as his pains and sufferings were so great immediately after he had drunk the beer. At last, by persuasion, he made the attempi, and the consequence was immediate convil. sions. When he was put to bed, it was with difficulty he was detained there. His convulsions increased, his features became more distnrted, his eyes were suffused with blood, and he appeared anxiously endeavouring to escape some idesl ofject; and such was the situation in which he was found by the writer. He was again pressed to take some water; and although his sufferings did not at the moment appear to be increased; still, as far as be was able, he persister in refusing, and it was evident he could not drink. From the symptoms, and from the rapid increase of the disease, it was considered necessary immediately to adopt some decisive measures; and the writer having read the 
successful treatment of hydrophobia, and the interesting communications related by Mr. Tymon and Dr. Shoolbred in the East Indies, he was determined without further loss of time to pursue to the utmost the means that bad been attended with such unusual success. Twenty uunces of blood were taken from the arm in six minutes. He fainted; and the pulse could scarcely be felt for one hour. His convulsions abated; his countenance had nearly lost all expression of distress; and, when he recovered, his first request was to be allowed to indulge in that which the bare idea of, but one hour before, seemed to be a source of the greatest suffering. He drank some water, and was greatly refreshed by it. At this period, no medicine whatever had been taken, nor for the space of two hours afterwards, and during the whole time he was comfurtable, and his bowels were relieved. He now commenced laking every three hours large doses of opiun, \&c. but, instead of his contimuing to enjoy ease and comfort, or further relicf from his bowels, his night was restless, and in the morning there appeared to be some reasons for apprehending a recurrence of the discase. Bleeding was again had recourse $t$ (", with similar success, excepting that the same effect was not produced upon the bowels, which possibly were rendered more difficult of action from the use of the opium, but which was afterwards effected by opening medicine. From this time no further symptom worthy of mention occurred, and the patient perfectly recovered.

It might here be remarked, that although hydrophobia in its very far advanced stages is generally described with wore force and violence of symptoms, yet it is presumed that the patient's symptoms and sufferings wert decidedly in consequence of that disease.

Particular attention is requested to the immediate alteration which took place in the disease, afier the abstraction of blond, and before any other remedy had been exhibited. With the testimony and assurance of Dr. Shoolbred, the writer felt sanguine in the result; and from his own experience of the success of rapid bleedings in diseases most resembling hydrophobia, he believes, if adopted in any stage of the disease where bleeding is admissible, and in the manner and to the extent required, it will be attended with as great a share of success as is usual in other diseases imminent in danger.

In confirmation that the success will depend upou the manner, and the extent, in which the operation is performed, the writer avails himself of the acknowledged high 


\section{Successful Treatment of a Case of Hydropholiu.}

and able authority of Dr. Cbristopher Robert Pemberton, who, when writing upon the subject of venesection in inflammatory diseases, expresses himself in the following Janguage :

"Physicians have been struck at all times with the effect produced by taking the blood from a large orifice in inflammatory diseases, and it is certainly a matter which cannot be too strougly urcred as an indispensable point in practice; especially as the generality of writers do not seem to have instituted any defined plan to regulate and secure the effectual performance of this operation. I wish, therefore, to press, in the strongest terms, the absolute necessity of attending to that circumstance, which the following observations may perhaps tend to elucidate.

"It is true, that from a small orifice the same quantity of blood may be taken as from a large one; but the time of its flowing is so long, that the topical inflammation, which demands for is relief a sudden efiect upon the system, is not in the luast influenced by it, though the general strength is much weakencd; which is an occurrence of all others to be avoided in a discase that requires repeated evaciations.

"As I consider this matter of great consequence, I shall endeavour to point ont a method, by which a plan, of a more defined nature than that hitherto adopted, moy be given for drawing blood in inflammatory diseases.

"At present we are contented to order that the blood should be taken from a large or from a small orifice, than which nothing surely can be more vague or undefined. The plan, which I propose, refers to the length of time in taking away the blood, which may be measured, and not the size of the orifice, which cannot.

"I find from numerous experiments, made at my desire. for this purpose by different surgeons, that when the orifice is such as to permit ejght onnees of blood to flow in three minutes, that then a patient under acute infammation will receive every benefit which is expected from the remedy. If it flows in a longer time, he $u$ ill receive less benefit; and, under certain circumstances, no benefit at all, or even an absolute injury.

"I can suppose a case of peripncumony, whercin a patient shall have just general strength cnough to carry on respitiation hy the ascistance of the voluntary muscles, and that ught cunces of blood shall be taken from a very small orifice, by which the change will be so gradual, in consequence of the time required for the blood to flow, that no alteration 
alteration whatever will be made in the dicease; but vet the general strength shall be so diminished, that death may ensue. On the other band, had the same quantity of blood been taken from a large orifice, that then the disease would have felt the remerly, and respiration would bave gone on with less exertion of the remaining general strength, in consequence of the lungs being relieved by this sudden depleison.

"The great conscquence, therefore, attached to the mode in which blood is drawn (as on this life or dealh may often (epend), imperiously demands of every physician to impress upon the mind of his patient the importance of the operation, and the absolute necessity of having it performed by a person fully skilled in his profession.

"I should not omit to mention, that there mav now and then occur a case, where the vein may not only be particularly small, but likewise be deeply seated, and covered with fat. Here, although the orifice may be sufficiently large, yet a portion of fat may obtrude so as to interrupt the stream of blood. I would in such case'recommend the surgeon to dilate the external orifice, or even make a fresh orifice, rather than persist in his endeavours to obtain the quantity required in this gradual way."

It has repeatedly happened to the writer to meet with those diseases, wherein it seemed unavoidably necessary to call to his aid the above strong and competent measures; and when he has been closely observing the state of the pulse during the operation, he has found that perbaps for about thiry or more pulsations (varving according to the strength and constitution of the patient) before the faintness supervenes, there is a perceptible increase of power, and great throbbing in the action of the hearl, the beart secming to struggle against being reduced to a state of subjection: this particular action of the bcart is generally sueceeded by diminished power in the circulation, and by which he is assured the discasc "has filt the remedy." He likewise wishes to add, that when the increased action of the heart begins to take place, the patient is generally very urgent that the blceding night be discontinued; but it is absolutely neccssary, in the writer's opinion, in extreme cases, to procced the one step further, namely, until faintness is produced. He prefers any other position for the patient to be placed in during the operation to one that is recumbent.

Before these observations are concluded, it might be well 
well to refer to the case of a Serjeant Clarke, related by Mr. Bellingen, Assistant-surgeon of the 1st Foot, and dated Trichinopoly, February 26th, 1813, and inserted in the Times paper, Angust 2ith, under the title "Hydrophobia." $1 \mathrm{t}$ is there considered " a case which appears to contradict this fortunate and promising one" (alluding to the successful case published by Dr. Shoolbred). In this instance, on the 23d February, at nine o'clock, a large orifice was opened in the patient's arm, and about 40 ounces of blood were taken. The patient complained of excessive languor, but did not fuint, yet some of the symptoms were diminished. At four o'clock bleeding was tried again; he struggled so much during the operation that the quantity could not be exactly ascertained, but it might be from 16 to 18 ounces. The pulse, after this bleeding, fell so low as to be scarcely discernible near the wrist, and towards the close he vomited a quantity of ropy phiegm mixed with frothy saliva. He continued to struggle violently for some time, then fell quiet for a few minutes, and expired about a quarter before five.

After a few further remarks, Mr. Bellingen concludes, "that blood-letting in this case had a timely trial." But it must be recollected, that in the first instance (although the quantity of blood taken was forty ounces) the patient only conplained of excessive languor, but did not fains. During the second bleeding, the pulse was scarcely discernible, but this was not three quarters of an hour before the patient died.

Without wishing to show any disrespect to the opinion of $\mathrm{Mr}$. Bellingen, might it not be inferred, that the first bleeding was incomplete?-for although the 40 ounces were taken, his patient did not faint-and that he was weakened, and the disease too far advanced for the second bleeding to have a chance of success?

XXXIV. Experiments on capillary Syphons with electrified and with heated Liquids.

$$
\text { To Mr. Tilloch. }
$$

$S_{I R},-I_{N}$ repeating the well known experiment of causing water to flow in a coristant stream from a capillary syphon, by means of the elcctric fluid, it struck me that this effect might be produced also by means of heat, because in many iustances the electric fluid so nearly resembles it. 